\title{
Farklı Soğutma Kanallarına Bir Kokil Kalıp Çekirdeğinin Termal Davranışlarının Nümerik Olarak İncelenmesi
}

\author{
Osman IPEK ${ }^{1}$, Mehmet KAN² \\ 1,2Süleyman Demirel Üniversitesi, Mühendislik Fakültesi, Makine Mühendislik Bölümü, 32260, Isparta, Türkiye
}

(Alınış / Received: 08.11.2020, Kabul / Accepted: 22.04.2021, Online Yayınlanma / Published Online: 15.08.2021)

\section{Anahtar Kelimeler}

Kokil Kalıp,

Soğutma Kanalı Tasarımı, HAD analizi
Özet: Bu çalışmada, farklı soğutma kanallarına sahip bir kokil kalıp çekirdeği nümerik olarak incelenmiştir. Klasik soğutma kanallı kalıp çekirdeği, kanatlı soğutma kanallı kalıp çekirdeği ve dalgalı soğutma kanallı kalıp çekirdeğinin 3DCAD çizimleri yapılmışıı. Elde edilen tasarımların termal davranışları Fluent yazılımı kullanılarak analiz edilmiştir. Soğutma performanslarının karşılaștırılması amacıyla, klasik, kanatlı ve dalgalı soğutma kanallı kalıp çekirdeklerinin termal davranışları nümerik olarak incelenmiştir. Erimiş metalin (Al6061 alüminyum alaşımı) kalıba dökülmesinden itibaren kalıp iç yüzeyinden 0-5. s zaman aralığında ve $0.5 \mathrm{~s}$ zaman adımlarıyla alınan verilerle kalıp çekirdeklerinden elde edilen ürünün (supap) sıcaklık dağılımı, katılaşma oranları karşılaștırmalı olarak irdelenmiştir. Soğutma performans sonuçlarının karşılaştırılmasından, supap sap kısmında kanatlı soğutma kanallı kalıp çekirdeğinin, supap baş kısmında dalgalı soğutma kanallı kalıp çekirdeğinin soğutma performansının daha iyi olduğu gözlemlenmiştir.

\section{Numerical Investigation of Thermal Behavior of a Permanent Mold Core to Different Cooling Channels}

\section{Keywords}

Permanent Mold, Cooling Channel Design, CFD Analysis

\begin{abstract}
In this study, a permanent mold core with different cooling channels is analyzed numerically. 3D-CAD drawings of classical cooling channel mold core, winged cooling channel mold core and curved cooling channel mold core were made. The thermal behaviors of the designs obtained were analyzed using Fluent software. In order to compare the cooling performances, the thermal behaviors of classical, winged and curved cooling channel mold cores were analyzed numerically. After the molten metal (Al6061 aluminum alloy) was poured into the mold, the temperature distribution and solidification rates of the product (valve) obtained from the mold cores were analyzed in comparison with the data obtained from the inner surface of the mold in a time interval of $0-5$. $\mathrm{s}$ and with $0.5 \mathrm{~s}$ time steps. Comparing the cooling performance results, it has been observed that the cooling performance of the mold core with winged cooling channels in the valve stem part and the mold core with curved cooling channels at the valve head part are better.
\end{abstract}

\section{Giriş}

Sanayinin temelinde, ürünlerin imalat parametrelerine uygun olarak üretilmesi ve bu ürünlerin problemsiz olarak birbirinin yerine kullanılabilmesi amaçlanmaktadır. Bu ürünlerin, seri ve ekonomik metotlarla imal edilmesi için yeni üretim teknikleri ortaya çlkmakta veya mevcut olanların geliştirilmesine katkı sağlamaktadır. Sıvı veya katı hammaddenin belirli şekil ve nitelikleri barındıran bir geometri içinde sıkıştırılması suretiyle imalatın gerçekleşmesi olarak tanımlanan kalıpçılık, birçok parçanın seri ve ucuz bir şekilde talep edilen özelliklerde imal edilmesi için en ideal metot olarak kullanılmaktadır. Teknolojik gelişmelerin artması ve bunun imalat proseslerine olan etkisi sebebiyle kalıpçılık önemli aşamalar kaydetmiş, önceden kalıp ile imalatı göz önünde bulundurulmayan parçalar bugün kalıp sektörü için çok kolay üretilebilecek duruma gelmiștir. Hızlı imalatın ve endüstrileșmenin ana esaslarından biri olan kalıpçılıkla üretilen parçaları kullanan sektörler arasında, otomotiv, inşaat, tekstil, plastik, elektronik, savunma, kauçuk ve lastik, cam sanayi gibi sanayi kolları başta 
gelmektedir. Kalıpçılık, ekonomiyi güçlendiren ve ekonominin gelişimini katkı sağlayan kesimlerin önde gelenlerinden birisidir. [1-7].

Metal kalıplar oldukça yüksek sıcaklıklarda çalışırlar. Yüksek sıcaklıklarda çalışmaları nedeniyle termal gerilme ve şekil deformasyonlarına maruz kalan kalıpların ömrü kısalmaktadır. Metal kalıpların tasarımında, erimiş metal ile kalıp arasındaki gerçekleşen ısı alış-verişi ile hal değişimine ilişkin malzeme özelliklerinin önceden belirlenmesi gerekmektedir [8-10]. Metal kalıplarda imalatı gerçekleştirilen ürünlerin kompleks geometrilere sahip olmalarından dolayı, 3D-CAD tasarımların yapılması gerekmektedir. Fakat üç boyutlu simülasyonlarda optimum sürede sonuca ulaşmak imalat için oldukça önem çok arz etmektedir. Metal kalıba döküm sırasında en çok karşılaşılan sorunlardan birisi de kalıp dizaynı olmaktadır. Özellikle kokil kalıp tasarımı farklı ve karmașık hesaplamalar içermektedir. Yüksek üretim maliyeti olan metal kalıpların amortisman süreleri, tasarım ömrüne göre daha kısa olması önemli problemlerden biri olarak gözükmektedir. [11]. Bu kalıpların tahmin edilen amortisman sürelerinden önce çalışma ömürlerini tamamlamaları büyük bir maliyet olușturmaktadır. $\mathrm{Bu}$ problemin temelinde kalıpların termal analizlerinin doğru bir şekilde yapılmamasından kaynaklanmaktadır.

Kokil kalıba döküm yöntemi ile üretilen parça malzemelerin mikro yapısının ince taneli ve mekanik özelliklerin daha iyi olması için homojen ve hızlı bir şekilde soğutulması gerekmektedir. Bu homojen ve hızlı soğutma aynı zamanda üretim hızını da arttırmaktadır. Bu sebeple parçaya özel geometride soğutma kanalı tasarımları yapılmış, homojen soğutma amacıyla soğutma kanallarının verimliliği ve üretim kalitesini geliştirmek için korelasyonlar türetilmiştir. Uygun soğutma kanallarıyla daha iyi bir ısı transferinin meydana geldiği teorik ve deneysel olarak ispatlanmıştır. Metal kalıplama yönteminde homojen olmayan soğutma sonucu meydana gelen kalıp hatalarını (parça çarpılmaları, eğilme ve sıcak nokta kusurları vb.) önlemek için çalıșmalar yapılmıştır. Kalıplama işlemi sırasında kalıp malzemelerinde gerilmeler, aşınmalar ve yapısal olarak deformasyonlar ortaya çıkmaktadır. Bu problemlerin kalıp yüzeyinde çatlaklara sebebiyet verdiği yapılan araştırmalarda görülmektedir [12-17]. Çalışmalarda, bu bozulmaları azaltmak için sonlu elemanlar stres modeli geliştirilmiş, bu model sayesinde ISı transferi hakkında korelasyonlar türetilmiştir. Üretilen numunelerin mikro yapıları ve mekanik özellikleri incelenmiştir [18-24].

Yapılan bu çalışmada, soğutma performanslarının karşılaștırılması amacıyla farklı soğutma kanallarına sahip bir kokil kalıp çekirdeği termal davranışları nümerik olarak incelenmiștir. Elde edilen tasarımların termal davranışları Fluent yazılımı kullanılarak analiz edilmiştir. Erimiş metalin (Al6061 alüminyum alaşımı) kalıba dökülmesinden itibaren kalıp iç yüzeyinden $0-5$. s zaman aralığında ve $0.5 \mathrm{~s}$ zaman adımlarıyla alınan verilerle kalıp çekirdeklerinden elde edilen ürünün (supap) sıcaklık dağılımı, katılaşma oranları karşılaştırmalı olarak irdelenmiştir. Kokil kalıp çekirdeğinde döküm parçası olarak otomotiv sektöründe termal ve dinamik etkiler altında çalışan, en kritik motor parçalarından birisi olan dizel içten yanmalı bir motorun egzoz supabı kullanılmıştır. Kalıp çekirdeğinde soğutma kanallarındaki akış nümerik olarak incelenmiştir. Yapılan analizlerde, soğutma performans sonuçlarının karşılaştırılmasından, supap sap kısmında kanatlı soğutma kanallı kalıp çekirdeğinin, supap baş kısmında dalgalı soğutma kanallı kalıp çekirdeğinin soğutma performansının daha iyi olduğu gözlemlenmiştir.

\section{Materyal ve Metot}

Bu çalışmada, kokil kalıp çekirdeğinde döküm parçası olarak otomotiv sektöründe termal ve dinamik etkiler altında çalışan, en kritik motor parçalarından birisi olan dizel içten yanmalı bir motorun egzoz supabı kullanılmıştır. Kalıp çekirdeğinde soğutma kanallarındaki akıș nümerik olarak incelenmiștir. Şekil 1'de görüldüğü gibi kokil kalıp çekirdeği katı modelinin simetri kalıp parçaları kompakt olarak tasarlanmıştır. Döküm parçası için optimum soğutma yapılması amacıyla klasik soğutma kanalları tasarlanmıştır.

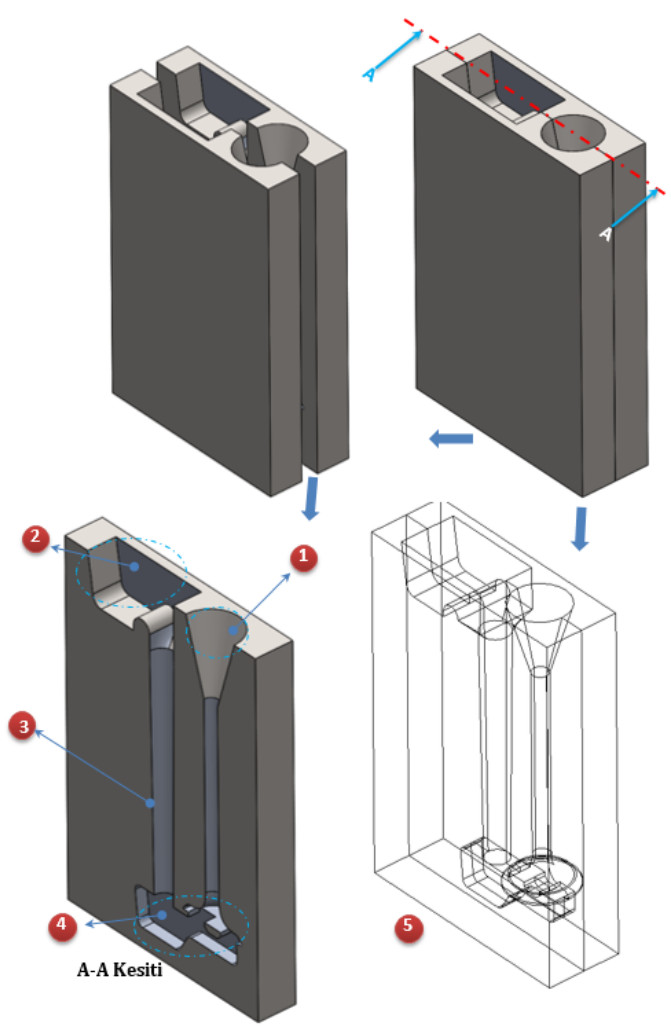

Şekil 1. Kokil kalıp çekirdeğinin 3D-CAD çizimi (1. Hava cebi, 2. Döküm havuzu, 3. Döküm yolluğu, 4. Döküm havuzu taban kısmı, 5. Kalıbın saydam görünüşü) 
Kokil kalıp çekirdeğinin çiziminden sonra Şekil 2'de verilen döküm parçası için optimum soğutma yapılması amacıyla soğutma kanalları tasarlanmıștır. Tasarlanan soğutma kanallarının, ısı transferine etkisi ve erimiş metalin katılaşması simetri durumundan dolayı kalıbın yarısı için nümerik olarak irdelenmiştir.
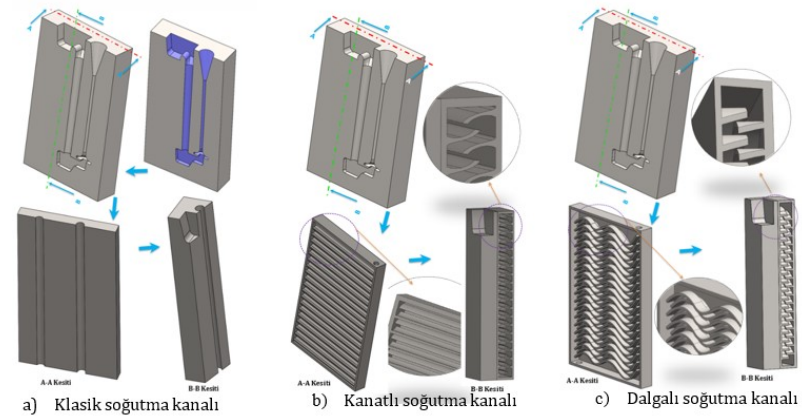

Şekil 2. Farklı soğutma kanal tasarımları

\subsection{Fluent Yazılımında Kullanılan Temel Denklemler ve Analiz Çözümlemesindeki Metotlar}

HAD (Hesaplamalı Akışkanlar Dinamiği) analizlerinde sayısal ağ yapısı oluşturulmuştur. Farklı soğutma kanallı kokil kalıp çekirdeklerinin akış hacmi modelleri için Tetra Hedral sayısal ağ yapısı geometrisi kullanılmıștır. $\mathrm{Bu}$ modelde ortalama 9.917,834 elaman, 5.694,075 adet düğüm noktası bulunmaktadır. Șekil 3' de görüldügü gibi metal kalıp çekirdeğinde dolaşan akışkana ait akış hacmi modeli oluşturulmuştur.
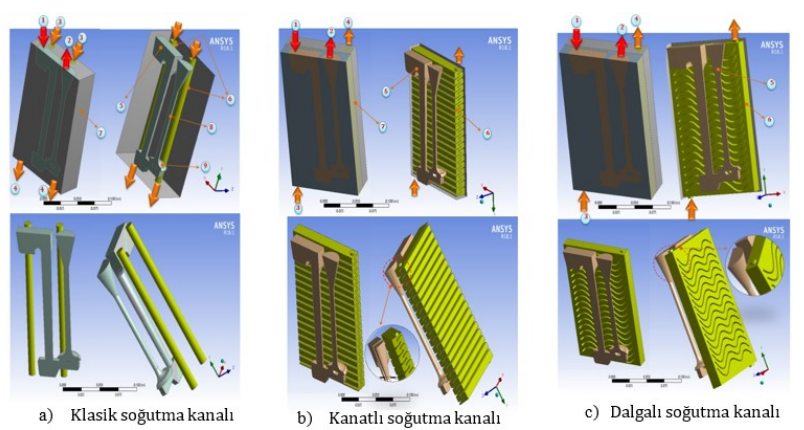

Şekil 3. Farklı soğutma kanalları için akış hacmi (1.Erimiş metalin kokil kalıba giriși, 2. Erimiş metalin kalıptan çıkış ağzı, 3. Soğutma akışkanının (ısı transfer yağı) kalıba girişi, 4. Soğutma akışkanının kalıptan çıkışı, 5. Erimiş metalin akış hacmi, 6. Soğutucu akışkanının akış hacmi, 7. Kalıp, 8. Supabın sap kısmı, 9. Supabın baş kısmı)

Sonlu hacimler metoduna dayanan bu yöntemde Fluent veya diğer modelleme programları kullanılmaktadır. Programlardan alınan sayısal ă yapısı dosyalarına sınır şartları ve parametreler uygulanarak sistemin çözümü yapılmaktadır. Sayısal çalışmada kullanılacak programlarda üç boyutlu ve zamana bağımlı kütlenin korunumu, momentum ve enerji denklemleri çözdürülecektir. Fluent programı, sistemi çözüme ulaştırmak için geri planda aşağıdaki denklemleri kullanmaktadır [25].

Kütle korunum denklemi Denklem 1'de gösterilmiştir.

$$
\nabla \cdot \vec{v}=\frac{\partial u}{\partial x}+\frac{\partial v}{\partial y}+\frac{\partial w}{\partial z}
$$

Momentum denklemi ise $\mathrm{X}, \mathrm{Y}$ ve $\mathrm{Z}$ eksenleri için Denklem 2-4' te verilmiștir:

$$
\begin{aligned}
& \rho\left(\frac{\partial \mathrm{u}}{\partial \mathrm{t}}+\mathrm{u} \frac{\partial \mathrm{u}}{\partial \mathrm{x}}+\mathrm{v} \frac{\partial \mathrm{u}}{\partial \mathrm{y}}+\mathrm{w} \frac{\partial \mathrm{u}}{\partial \mathrm{z}}\right)=\mu\left(\frac{\partial^{2} \mathrm{u}}{\partial \mathrm{x}^{2}}+\frac{\partial^{2} \mathrm{u}}{\partial \mathrm{y}^{2}}+\right. \\
& \left.\frac{\partial^{2} \mathrm{u}}{\partial \mathrm{z}^{2}}\right)-\frac{\partial \mathrm{P}}{\partial \mathrm{x}}+\rho g_{\mathrm{x}} \\
& \rho\left(\frac{\partial \mathrm{v}}{\partial \mathrm{t}}+\mathrm{u} \frac{\partial \mathrm{v}}{\partial \mathrm{x}}+\mathrm{v} \frac{\partial \mathrm{v}}{\partial \mathrm{y}}+\mathrm{w} \frac{\partial \mathrm{v}}{\partial \mathrm{z}}\right)=\mu\left(\frac{\partial^{2} \mathrm{v}}{\partial \mathrm{x}^{2}}+\frac{\partial^{2} \mathrm{v}}{\partial \mathrm{y}^{2}}+\frac{\partial^{2} \mathrm{v}}{\partial \mathrm{z}^{2}}\right)- \\
& \frac{\partial \mathrm{P}}{\partial \mathrm{x}}+\rho g_{\mathrm{y}} \\
& \rho\left(\frac{\partial \mathrm{w}}{\partial \mathrm{t}}+\mathrm{u} \frac{\partial \mathrm{w}}{\partial \mathrm{x}}+\mathrm{v} \frac{\partial \mathrm{w}}{\partial \mathrm{y}}+\mathrm{w} \frac{\partial \mathrm{w}}{\partial \mathrm{z}}\right)=\mu\left(\frac{\partial^{2} \mathrm{w}}{\partial \mathrm{x}^{2}}+\frac{\partial^{2} \mathrm{w}}{\partial \mathrm{y}^{2}}+\right. \\
& \left.\frac{\partial^{2} \mathrm{w}}{\partial \mathrm{z}^{2}}\right)-\frac{\partial \mathrm{P}}{\partial \mathrm{x}}+\rho \mathrm{g}_{\mathrm{z}}
\end{aligned}
$$

Enerjinin korunumu denklemi (Denklem 5) aşağıda verilmiştir.

$$
\begin{aligned}
& \rho\left[\frac{\partial\left(\mathrm{C}_{\mathrm{p}} \mathrm{T}\right)}{\partial \mathrm{t}}+\frac{\partial\left(\mathrm{C}_{\mathrm{p}} \mathrm{uT}\right)}{\partial \mathrm{x}}+\frac{\partial\left(\mathrm{C}_{\mathrm{p} v \mathrm{~T}}\right)}{\partial \mathrm{y}}+\frac{\partial\left(\mathrm{C}_{\mathrm{p}} \mathrm{wT}\right)}{\partial \mathrm{z}}\right]= \\
& \frac{\partial}{\partial \mathrm{x}}\left(\mathrm{k} \frac{\partial \mathrm{T}}{\partial \mathrm{x}}\right)+\frac{\partial}{\partial \mathrm{y}}\left(\mathrm{k} \frac{\partial \mathrm{T}}{\partial \mathrm{y}}\right)+\frac{\partial}{\partial \mathrm{z}}\left(\mathrm{k} \frac{\partial \mathrm{T}}{\partial \mathrm{z}}\right)
\end{aligned}
$$

Tablo 1'de nümerik hesaplamalarda kullanılan yaklaşımlar, belirlenen parametreler ve sınır şartlarına ait değerler belirlenmiştir. Ayrıca kalıp malzeme özellikleri, döküm malzeme özellikleri ve soğutucu akışkanın özellikleri de verilmiştir.

Tablo 1. Nümerik hesaplamalarda kullanılan yaklaşımlar, parametreler [25]

\begin{tabular}{|c|c|}
\hline Simülasyon koşulu & $\begin{array}{c}\text { Zamana bağlı durum } \\
\text { (Transient-state) }\end{array}$ \\
\hline Çözücü tipi & Basınca dayalı çözücü \\
\hline Viskoz model & $\begin{array}{c}\text { Standard k }-\varepsilon \text { türbülans } \\
\text { modeli }\end{array}$ \\
\hline Hız-basınç etkileşimi & COUPLED algoritması \\
\hline Ayrıklaştırma yöntemi & $\begin{array}{c}\text { İkinci dereceden merkezi } \\
\text { farklar metodu }\end{array}$ \\
\hline $\begin{array}{c}\text { Basınç, momentum ve } \\
\text { enerji denklemleri }\end{array}$ & $\begin{array}{c}\text { İkinci dereceden merkezi } \\
\text { farklar metodu }\end{array}$ \\
\hline $\begin{array}{c}\text { Türbülans kinetik enerji } \\
\text { ve türbülans dağılım oranı }\end{array}$ & $\begin{array}{c}\text { İkinci dereceden merkezi } \\
\text { farklar metodu }\end{array}$ \\
\hline $\begin{array}{c}\text { COUPLED (Birleşik) } \\
\text { algoritması }\end{array}$ & $\begin{array}{c}\text { Poseido-Transient Explicit } \\
\text { (açı) çözüm }\end{array}$ \\
\hline
\end{tabular}

\subsection{Kokil Kalıp Çekirdeğinin Matematiksel Analizi}

Yapılan çalışmada faz dönüşümü ve sıcaklığa bağlı malzeme özellikleri mevcut olduğundan, dökümün katılaşması esnasında ve kalıp çekirdeğindeki ısı transferinde doğrusal olmayan zamana bağlı (transient) denklemler kullanılmıștır. Bu çalıșmada zamana bağlı yapılan hesaplamalarda, erimiş sıcaklığı 973 K' de kabul edilerek soğutma kanalları tarafından meydana gelen ısı akısı hesaplanmıștır [26]. Erimiș metal 973 K'den 543 K sıcaklığa soğuduğu varsayılarak teorik bir $\dot{\mathrm{Q}}_{\mathrm{Al}}$ değeri hesaplanmıştır (Denklem 6).

$$
\dot{\mathrm{Q}}_{\mathrm{Al}}=\frac{\mathrm{Q}_{\mathrm{Al}}}{\mathrm{dt}}
$$


Eriyik metalin katılaşması sırasında çekilmesi gereken ısı duyulur $\left(\dot{\mathrm{Q}}_{\text {duy }}\right)$ ve ve gizli $\left(\dot{\mathrm{Q}}_{\text {giz }}\right)$ isıların toplamıdır (Denklem 7);

$$
\dot{\mathrm{Q}}_{\mathrm{Al}}=\dot{\mathrm{Q}}_{\mathrm{duy}}+\dot{\mathrm{Q}}_{\mathrm{giz}}
$$

Gizli ısı ve duyulur ısılar aşağıda verilmiştir. (Denklem 8-9).

$$
\begin{gathered}
\dot{\mathrm{Q}}_{\mathrm{duy}}=\dot{\mathrm{m}}_{\mathrm{Al}} \mathrm{c}_{\mathrm{p}, \mathrm{Al}} \Delta \mathrm{T} \\
\dot{\mathrm{Q}}_{\mathrm{giz}}=\dot{\mathrm{m}}_{\mathrm{Al}} \mathrm{LH}
\end{gathered}
$$

Burada LH (J/kg.), bir kg metal alaşımın erimesi için verilmesi gereken ısı veya gizli ısı füzyonunu, $\dot{\mathrm{m}}_{\mathrm{Al}}$ (kg/s), erimiş Al metal alaşımının kütlesel debisini, $\mathrm{c}_{\mathrm{p}, \mathrm{Al}}(\mathrm{J} / \mathrm{kgK}), \mathrm{Al}$ alaşım eriyiğinin özgül ısısını ifade etmektedir. $\mathrm{LH}=500000 \mathrm{~J} / \mathrm{kg}$ olarak alınmıștır.

\section{Bulgular}

Analizler, klasik, kanatlı ve dalgalı soğutma kanallı kalıp çekirdekleri olmak üzere üç farklı soğutma kanalları dikkate alınarak yapılmıștır. Kokil kalıplama yöntemiyle, egzoz supabı üretilmesine yönelik analiz sonuçları, üretimde kullanılan sıvı metalin katılaşma süresi ve elde edilen ürün üzerindeki sıcaklık dağılımları farklı soğutma kanalları için karşılaştırmalı olarak incelenmiştir. Şekil 4'te görüldüğü gibi, analizler, kalıp çekirdeği ve erimiş metalin sıcaklık dağılımları, 3D-CAD tasarımıyla elde edilen üç farklı soğutma kanallı kalıp çekirdeğinin simetrisi üzerinde gerçekleştirilmiştir. Sonuçları karşılaştırmak amacıyla, kalıp çekirdeğinin simetrisi üzerinde sıvı metalin katılaşma ve sıcaklık dağılımı analizlerinin yapıldığı bölgeler gösterilmiştir.

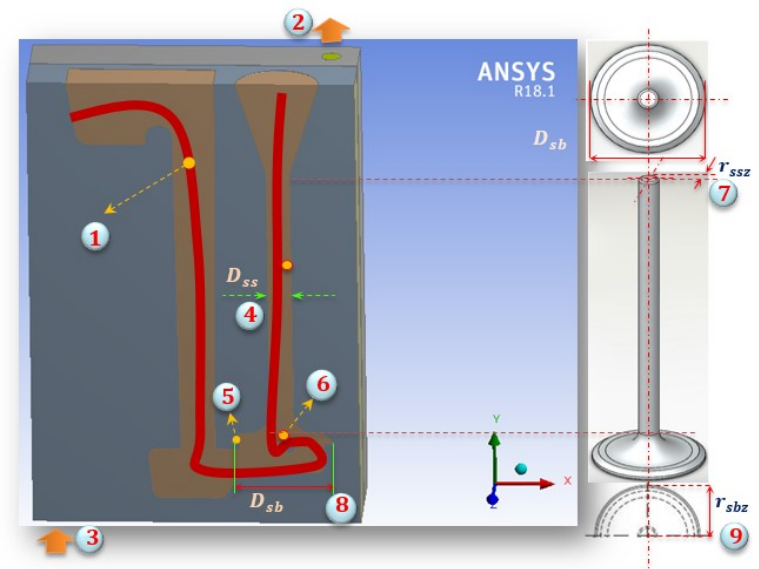

Şekil 4. Simetri kalıp çekirdeği üzerinde yapılan analiz sonuçlarının sıcaklık ve sıvı metal katılaşma oranı baz alınarak yapılan karşılaştırma bölgeleri (1. Nümerik analizlerin yapıldığı bölge, 2. Soğutucu akışkan çıkışı, 3. Soğutucu akışkan giriși, 4. Supap sap çapı $\left(D_{s s}\right)$ 5. Supap bașının yanak kısmı, 6. Supap bașının merkezi, 7. z ekseni yönünde supap sapı yarıçapı $\left(\mathrm{r}_{\mathrm{ssz}}\right), 8$. Supap başı çapı $\left(\mathrm{D}_{\mathrm{bs}}\right)$, 9. z ekseni yönünde supap başı yarıçapı $\left.\left(\mathrm{r}_{\mathrm{sbz}}\right)\right)$

Şekil 5'te, klasik soğutma kanalı için dökümden sonraki ilk 0.5-5. s aralıklarındaki supap ekseni boyunca sıcaklık dağılım konturlarının supap yüksekliğine bağlı olan değişimleri verilmiştir.
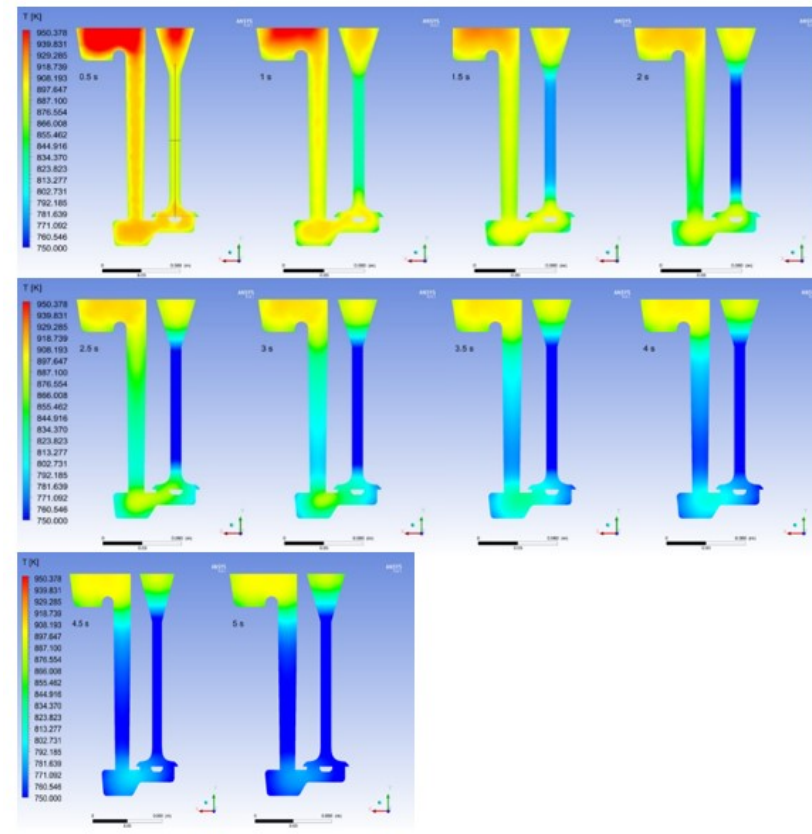

Şekil 5. Klasik soğutma kanalı için supap üzerinde zamana bağlı sıcaklık konturları

Şekil 5'te, soğutma işleminin başlamasıyla birlikte metal sıcaklığının zamana bağlı olarak, azaldığı, 2. s'den sonra supabın sap kısmında zamana bağlı olarak 743.245 - 670.585 K arasında değiștiği görülmektedir. Proses zamanının her 0.5 s'lik artışıyla, supap sapındaki sıcaklık ortalama $50{ }^{\circ} \mathrm{C}$ düşmüștür. $\mathrm{Bu}$ sonuçlara göre, supap başının soğuma hızının, supap sapına göre daha yavaş olduğu görülmüștür. Döküm havuzu, yolluk ve döküm havuzu tabanında soğuma gerçekleşmemiştir. En hızlı soğuma ilk 1. s içerisinde gerçekleşirken sonraki zaman dilimlerinde soğuma hızı kısmen yavașlamaktadır. Buna göre, amaç hızlı soğumayı gerçekleştirmek ise, kalıp çekirdeği üzerinde uygun tasarlanmış soğutma kanallarının kullanılması gerektiği anlaşılmaktadır.

Şekil 6'da, kanatlı soğutma kanalı için dökümden sonraki ilk 0.5-5. s aralıklarındaki supap ekseni boyunca sıcaklık dağılım konturlarının supap yüksekliğine bağlı olan değișimleri verilmiștir.

Şekil 6'dan da görüldüğü gibi, kanatlı soğutma kanallı kalıp çekirdeğinde, supabın baş bölgesi ile sap bölgesine ait sıcaklık dağılımındaki fark dikkati çekmektedir. Soğutma işleminin başlamasıyla birlikte metal sıcaklığının zamana bağlı olarak, azaldı ̆̆ı, 2. s'den sonra supabın sap kısmında zamana bağlı olarak 743.633 - 670.433 K arasında değiștiği görülmektedir. Proses zamanının her 0.5 s'lik artışıyla, supap sapındaki sıcaklık ortalama $39{ }^{\circ} \mathrm{C}$ düşmüștür.

Şekil 7'de dalgalı soğutma kanallı kalıp çekirdeği için erimiş metalin kalıp boşluğuna dökülmesinden sonra 0.5-5. s zaman aralığında ortaya çıkan sıcaklık dağılımlarına ait kontur grafikleri verilmiştir. 


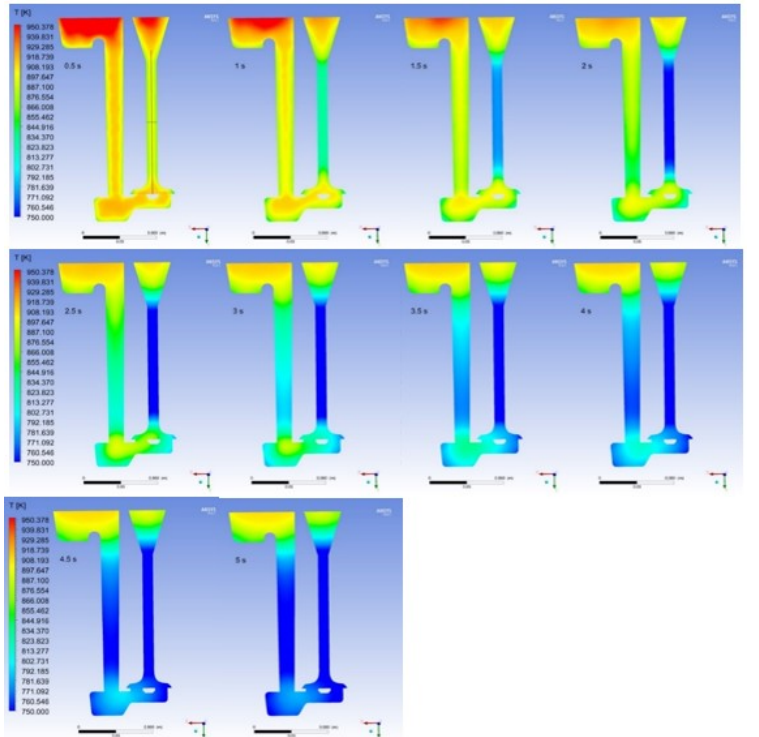

Şekil 6. Kanatlı soğutma kanalı için supap üzerinde zamana bağlı sıcaklık konturları

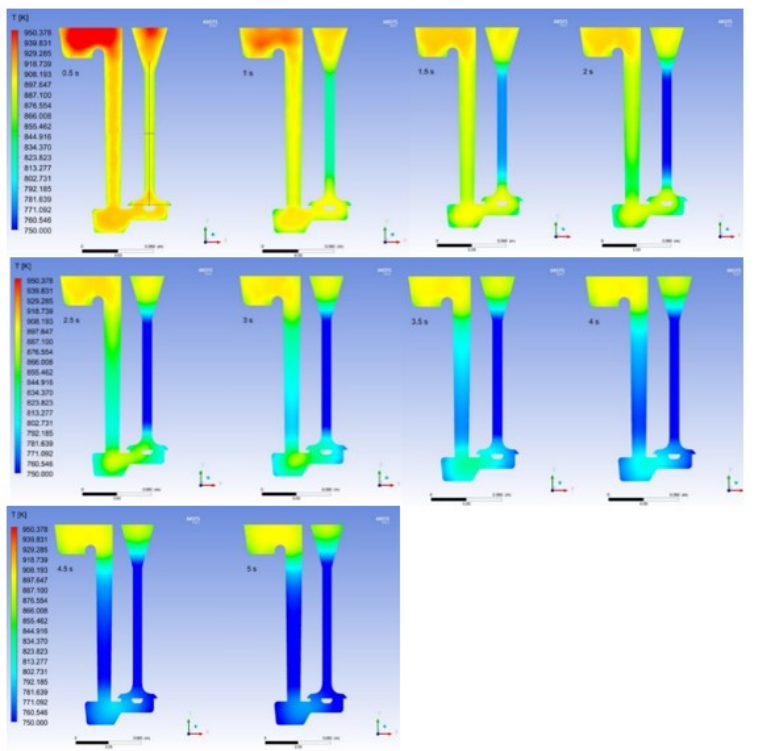

Şekil 7. Dalgalı soğutma kanalı için supap üzerinde zamana bağlı sıcaklık konturları

Şekil 7'den de görüldüğü üzere; dalgalı soğutma kanallı kalıp çekirdeğinde, supabın baş bölgesi ile sap bölgesine ait sıcaklık dağılımındaki fark dikkati çekmektedir. Soğutma işleminin başlamasıyla birlikte metal sıcaklığının zamana bağlı olarak, azaldığı, 2. s'den sonra supabın sap kısmında zamana bağlı olarak 743.300 - 669.484 Karasında değiștiği görülmektedir. Proses zamanının her 0.5 s'lik artışıyla, supap sapındaki sıcaklık ortalama $40{ }^{\circ} \mathrm{C}$ düşmüştür.

Kalıp çekirdeği üzerindeki soğutma kanallarının kalıba dökülen erimiş metalin sıcaklık değişimi üzerindeki etkisi gözlemlenirken, sıvı metalin katılaşma sürecini incelenmiştir. Bu amaçla, klasik soğutma kanallı kalıp çekirdeği kullanılarak yapılan kokil kalıpla döküm işlemi için 0.5-5. s zaman aralığında ve $0.5 \mathrm{~s}$ zaman adımları ile yolluk ve supap üzerindeki sıvı metal hacim oranı (SMHO) değişimine ait kontur grafikler Şekil 8'de verilmiștir.
Şekil 8'de gösterildiği gibi, katılaşmanın, supap sapı ve yollukta dış yüzeyden merkeze doğru gerçekleștiği, 0.5. s'nin sonunda supap sapında katılaşmanın büyük oranda tamamlandığı görülmektedir. Supap sapı dış yüzeyi ve merkezindeki sıvı metal hacim oranları ise 0.5 . s'de sirasiyla; 0.0281 ve 0.634 olurken 1 . s'nin sonunda, supap sapı çapı $D_{s s}$ üzerinde katılaşma tamamlanmaktadır. Bütün soğutma zamanları için, supap başında katılaşma ise 2.5 s'nin sonunda gerçekleşmektedir. $\mathrm{Bu}$ aşamada, yolluk girişi merkezinde, döküm havuzu merkezinde ve yolluk çıkışı merkezindeki SMHO'larının sırasıyla 0.940, 0.396 ve 0.705 olduğu görülmüştür.

Şekil 9'da kanatlı soğutma kanallı kalıp çekirdeği için de $0.5-5$. s zaman aralığında ve $0.5 \mathrm{~s}$ zaman adımları ile yolluk ve supap üzerindeki sıvı metal hacim oranı (SMHO) değişimine ait kontur grafikleri verilmiştir.

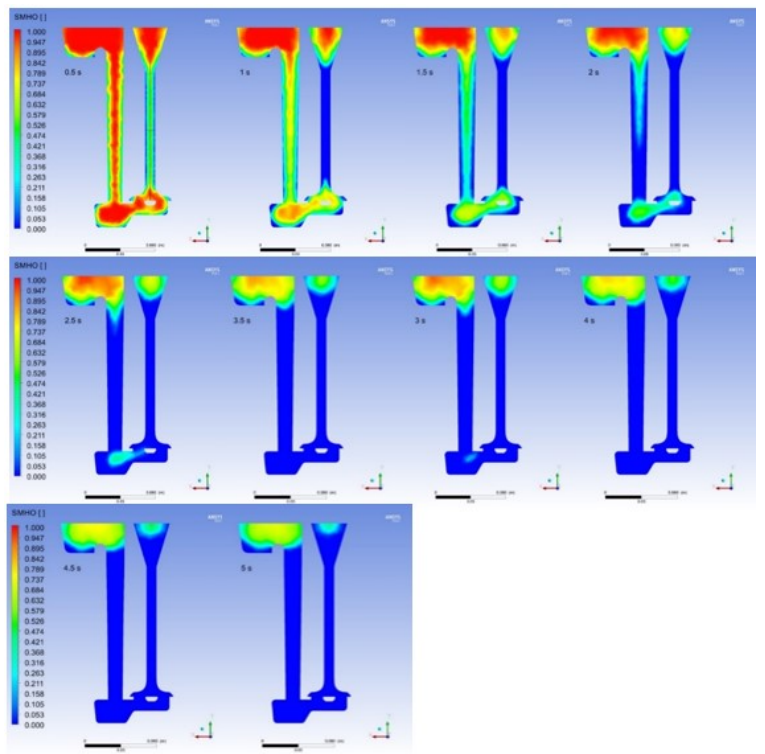

Şekil 8. Klasik soğutma kanalı için supap üzerinde zamana bağlı sıvı metal hacim oranı konturları

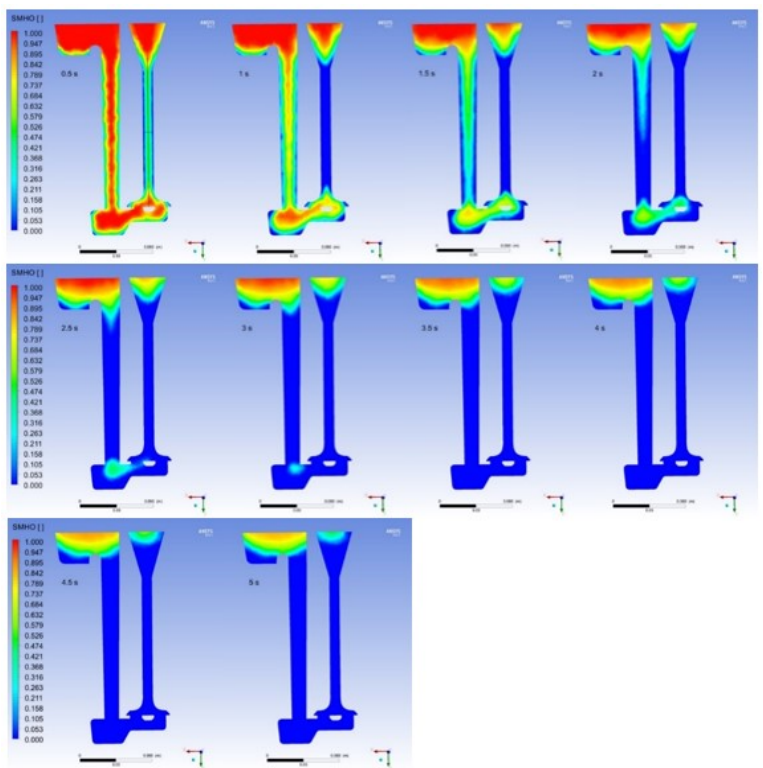

Şekil 9. Kanatlı Soğutma Kanalı için Supap Üzerinde Zamana Bağlı sıvı metal hacim oranı Konturları 
Şekil 9'dan da görülebileceği gibi, katılaşmanın, supap sapı ve yollukta dış yüzeyden merkeze doğru gerçekleștiği, 1. s'nin sonunda supap sapında katılaşmanın büyük oranda tamamlandı̆̆ görülmektedir. Supap sapı dış yüzeyi ve merkezindeki sıvı metal hacim oranları ise 0.5. s'de sirasıyla; 0.058 ve 0.545 olurken 1 . s'nin sonunda, supap sapı çapı $D_{s s}$ üzerinde katılaşma tamamlanmaktadır. Bütün soğutma zamanları için, supap başında katılaşma ise 3 . s'nin sonunda gerçekleşmektedir. Bu aşamada, yolluk girişi merkezinde, döküm havuzu merkezinde ve yolluk çıkışı merkezindeki SMHO'larının sırasıyla 0.907, 0.317 ve 0.534 olduğu görülmüştür.

Şekil 10'da dalgalı soğutma kanallı kalıp çekirdeği kullanılarak yapılan kokil kalıpla döküm işlemi için 0.5-5. s zaman aralığında ve $0.5 \mathrm{~s}$ zaman adımları ile yolluk ve supap üzerindeki sıvı metal hacim oranı (SMHO) değişimine ait kontur grafikleri verilmiştir.

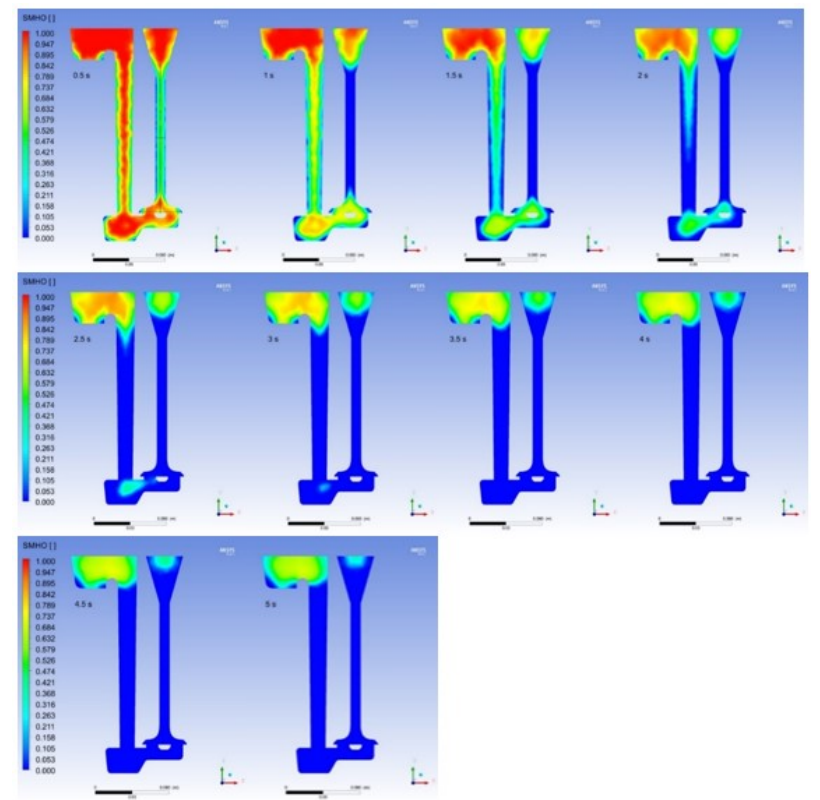

Şekil 10. Dalgalı soğutma kanalı için supap üzerinde zamana bağlı sıvı metal hacim oranı konturları

Şekil 10'dan da görülebileceği gibi, katılaşmanın, supap sapı ve yollukta dış yüzeyden merkeze doğru gerçekleştiği, 0.5. s'nin sonunda supap sapında katılaşmanın büyük oranda tamamlandığı görülmektedir. Supap sapı dış yüzeyi ve merkezindeki sıvı metal hacim oranları ise 0.5 . s'de sırasıyla; 0.0362 ve 0.597 olurken 1 . s'nin sonunda, supap sapı çapı $D_{s s}$ üzerinde katılaşma tamamlanmaktadır. Bütün soğutma zamanları için, supap başında katılaşma ise 2.5 s'nin sonunda gerçekleşmektedir. Bu aşamada, yolluk girişi merkezinde, döküm havuzu merkezinde ve yolluk çıkışı merkezindeki SMHO'larının sırasıyla $0.930,0.341$ ve 0.409 olduğu görülmüștür.

Şekil 11, Şekil 12 ve Şekil 13'te farklı soğutma kanallı kalıp çekirdeği için supap sapı çapı $\left(\mathrm{D}_{\mathrm{ss}}, 8\right)$ boyunca, $\mathrm{z}$ ekseni yönünde supap sapı yarıçapı $\left(\mathrm{r}_{\mathrm{ssz}}, 11\right)$ boyunca ve $z$ ekseni yönünde supap başı yarıçapı $r_{\text {sbz }}$ boyunca SMHO dağılımları verilmiştir.

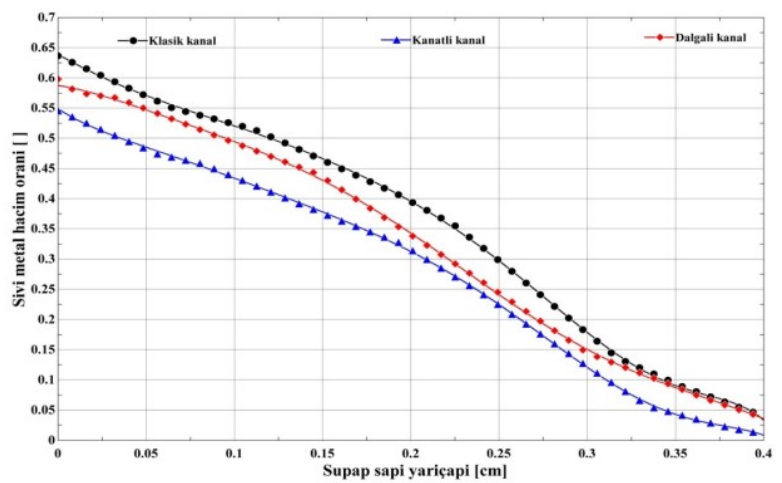

Şekil 11. Farklı soğutma kanallı kalıp çekirdeği için supap sapı çapı $\left(D_{s s}, 8\right)$ boyunca SMHO değerlerinin zamana bağlı değişimi

Şekil 11'de görüldüğü üzere; farklı soğutma kanallı kalıp çekirdeği için supap sapı çapı $\left(D_{s s}, 8\right)$ boyunca SMHO dağılımlarının farklılıklar göstermektedir. Supap sapı merkezine doğru maksimuma ulaşmaktadır. Klasik soğutma kanallı kalıp çekirdeğinde $0.40-0.45$. cm, kanatlı soğutma kanallı kalıp çekirdeğinde $0.37-0.42$. cm ve dalgalı soğutma kanallı kalıp çekirdeğinde ise 0.39-0.42. cm'ler arasında maksimumdan geçmektedir.

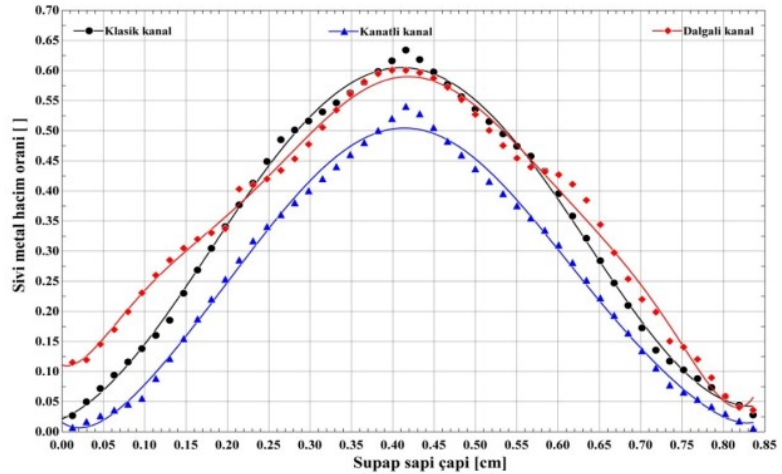

Şekil 12. Farklı soğutma kanallı kalıp çekirdeği için supap sapı yarıçapı $\left(\mathrm{r}_{\mathrm{ssz}}, 11\right)$ boyunca SMHO değerlerinin zamana bağlı değişimi

Şekil 12'de; farklı soğutma kanallı kalıp çekirdeği için supap sapı yarıçapı $\left(\mathrm{r}_{\mathrm{ssz}}, 11\right)$ boyunca SMHO dağılımlarının döküm yüzeyinden kalıba doğru azaldığı gözlemlenmiştir. Supap sapı yarıçapı boyunca SMHO değerleri klasik soğutma kanallı kalıp çekirdeği, kanatlı soğutma kanallı kalıp çekirdeği ve dalgalı soğutma kanallı kalıp çekirdeğinde sırasıyla 0.69-0, 0.55-0 ve 0.59-0 değerlerine aralığında katılaşmaktadır.

Şekil 13'ten de görüldüğü gibi; farklı soğutma kanallı kalıp çekirdeği için 0.5. s'de z ekseni üzerinde supap başı yarıçapı $\left(\mathrm{r}_{\mathrm{sbz}}, 13\right)$ boyunca SMHO dağılımlarının döküm yüzeyinden kalıba doğru azaldığı gözlemlenmiștir. Supap sapı yarıçapı boyunca SMHO değerleri klasik soğutma kanallı kalıp çekirdeği, kanatlı soğutma kanallı kalıp çekirdeği ve dalgalı soğutma kanallı kalıp çekirdeğinde sırasıyla 0.90-0, 0.85-0 ve 0.69-0 değerlerine aralığında katılaşmaktadır. 


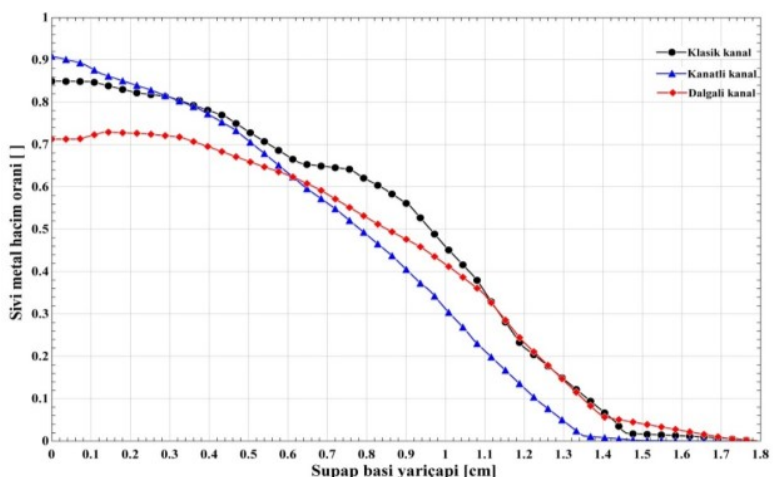

Şekil 13. Farklı soğutma kanallı kalıp çekirdeği için 0.5. s'de $\mathrm{z}$ ekseni üzerinde supap başı yarıçapı $\left(\mathrm{r}_{\mathrm{sbz}}, 13\right)$ boyunca SMHO değerlerinin zamana bağlı değişimi

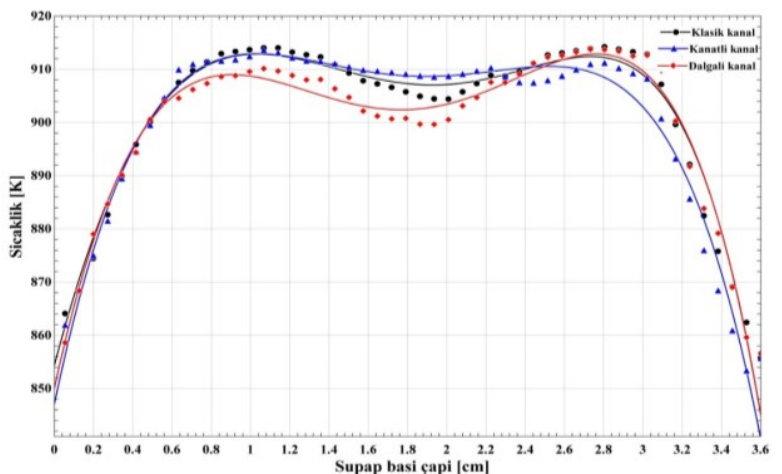

Şekil 14. Farklı soğutma kanallı kalıp çekirdeği için 0.5. s'de $\mathrm{z}$ ekseni üzerinde supap başı çapı $\left(\mathrm{D}_{\mathrm{sb}}, 12\right)$ boyunca sıcaklığın zamana bağlı değişimi

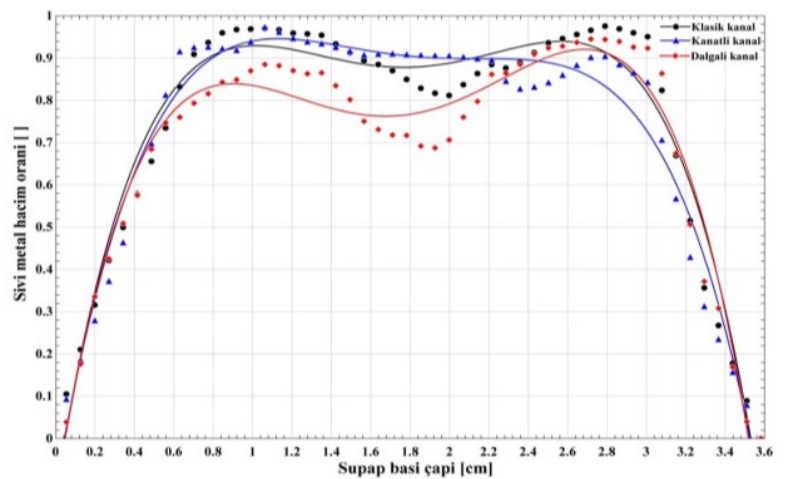

Şekil 15. Farklı soğutma kanallı kalıp çekirdeği için 0.5. s'de z ekseni üzerinde supap başı çapı $\left(D_{s b}, 12\right)$ boyunca SMHO değerlerinin zamana bağlı değişimi

Şekil 14'te farklı soğutma kanallı kalıp çekirdeği için 0.5. s'de z ekseni üzerinde supap başı çapı $\left(D_{s b}, 12\right)$ boyunca sıcaklığın zamana bağlı değişimi ve Şekil 15 'te farklı soğutma kanalları için 0.5. s'de z ekseni üzerinde supap başı çapı $\left(D_{s b}, 12\right)$ boyunca SMHO değerlerinin zamana bağlı değişimi verilmiştir.

Şekil 14'te; farklı soğutma kanallı kalıp çekirdeği için 0.5. s'de z ekseni üzerinde supap başı yarıçapı $\left(D_{s b}\right.$, 12) boyunca sıcaklık dağılımlarının dökümün başlamasıyla sıcaklığının önce arttığı, döküm yüzeyinden supap başı merkezine doğru azaldığı gözlemlenmiştir. Supap başı merkezinden kalıba doğru tekrar arttığı kalıbın yüzeyinde ise azaldığı gözlemlenmiştir. Supap başı yarıçapı boyunca sıcaklık değerleri klasik soğutma kanallı kalıp çekirdeği, kanatlı soğutma kanallı kalıp çekirdeği ve dalgalı soğutma kanallı kalıp çekirdeğinde sırasıyla $0.6-1 . \mathrm{cm}$ ve $2.4-3.2 \mathrm{~cm}, 0.6-0.9 \mathrm{~cm}$ ve $2.6-3.0$. cm ve $0.6-0.9$ $\mathrm{cm}$ ve 2.6 -3.0. cm'ler arasında yine iki maksimumdan geçmektedir.

Şekil 15'te; farklı soğutma kanallı kalıp çekirdeği için 0.5 . s'de z ekseni üzerinde supap başı yarıçapı $\left(D_{s b}\right.$, 12) boyunca SMHO dağılımlarının dökümün başlamasıyla sıcaklığının önce arttı̆̆ı, döküm yüzeyinden supap başı merkezine doğru azaldığı gözlemlenmiştir. Supap başı merkezinden kalıba doğru tekrar arttığı kalıbın yüzeyinde ise azaldığı gözlemlenmiştir. Supap başı yarıçapı boyunca sıcaklık değerleri klasik soğutma kanallı kalıp çekirdeği, kanatlı soğutma kanallı kalıp çekirdeği ve dalgalı soğutma kanallı kalıp çekirdeğinde sırasıyla 0.8-1.2. $\mathrm{cm}$ ve $2.4-3.2 \mathrm{~cm}, 0.6-1 \mathrm{~cm}$ ve $2.4-2.8$. cm ve $0.6-1 \mathrm{~cm}$ ve $2.4-2.8$. cm'ler arasinda yine iki maksimumdan geçmektedir.

\section{Tartışma ve Sonuç}

Yapılan bu çalıșma kapsamında, erimiș metali kokil kalıba döküm yöntemiyle egzoz supabı elde edilmesi için, mevcut döküm yöntemleri ve bu yöntemlerde kullanılan kalıp soğutma kanalları incelenmiş, DMLS metoduyla kalıp çekirdeğinin üretiminde, kalıp çekirdeği üzerinde nitelikli soğutma kanallarının elde edilmesi ve yolluk uygulaması için 3D-CAD tasarımları gerçekleştirilmiştir. Öncelikli olarak klasik soğutma kanalı kalıp çekirdeği tasarımı yapılmıștır. Daha sonra iki farklı özgün soğutma kanallı kalıp çekirdeği tasarlanmıştır. $\mathrm{Bu}$ tasarımlar üzerinde, Fluent programı kullanılarak nümerik analiz çalışmaları yapılmıştır. Fluent programı kullanılarak yapılan nümerik hesaplamalarda, kalıp çekirdeği içerisinde sirküle edecek soğutucu akışkanın kanal içindeki akıș ve termal davranışları, kalıp çekirdeği ve üretilen egzoz supabı üzerindeki termal ve dinamik parametrelerin değişiminin belirlenmesi amacıyla, HAD analizlerinden yararlanılmıștır. Egzoz supabının sap kısmından alınan verilerde kanatlı soğutma kanallı kalıp çekirdeğinin supap baş kısmında ise dalgalı soğutma kanallı kalıp çekirdeğinin daha iyi olduğu görülmüștür. Supap baș kısmının daha kalın cidara sahip olması nedeniyle soğutulmasının daha zor olması göz önüne alınarak dalgalı soğutma kanallı kalıp çekirdeğinde en iyi soğutma performansı gerçekleştirilmiştir.

Özgün soğutma kanallı kalıp çekirdeği tasarımı, imalatı ve optimum çalışma şartlarının belirlenmesi konusunda ileride yapılacak uygulamalara katkı sağlayacaktır. Bu çalışmadaki tasarımlar yapılacak olan özgün soğutma kanallı kalıp çekirdeklerinin yolluk, itici ve soğutma sistemlerinin iyileștirilmesinde yarar sağlayacaktır.

Tasarımlar yapıldıktan sonra analizlerle özgün soğutma kanallı kalıp çekirdeğinin soğutma performansına katkısı olacaktır. Analizlerin, özgün 
soğutma kanallı kalıp çekirdeklerinde imalata geçilmeden önce gerekli revizelerin yapılmasına ve imalat için maliyetin azalmasına yardımcı olması beklenmektedir. Ayrıca yapılacak analizlerle kalıp çekirdeklerinde yolluk ve soğutma sistemlerinin geliştirilmesine katkı sağlayacaktır.

Yapılacak olan çalışmalarda, HAD analizleri vasıtasıyla kalıp soğutucu gibi karışık geometrilere sahip imalatı zor parçaların parametrik ve geometrik optimizasyonu yapılarak, DMLS metodu ile imalatı kolaylıkla yapılabilecektir.

\section{Teşekkür}

ÖYP05285-DR-14 No`lu Proje ile tezimi maddi olarak destekleyen Süleyman Demirel Üniversitesi Bilimsel Araştırma Projeleri Yönetim Birimi Başkanlığı'na teşekkür ederim. Bu çalışma, Prof. Dr. Osman IPEK danışmanlığında Mehmet KAN'nın doktora tezinden hazırlanmıştır.

\section{Etik Beyanı}

Bu çalışmada, "Yükseköğretim Kurumları Bilimsel Araştırma ve Yayın Etiği Yönergesi" kapsamında uyulması gerekli tüm kurallara uyulduğunu, bahsi geçen yönergenin "Bilimsel Araştırma ve Yayın Etiğine Aykırı Eylemler" başlığı altında belirtilen eylemlerden hiçbirinin gerçekleștirilmediğini taahhüt ederiz.

\section{Kaynakça}

[1] Amend, P.,Pscherer, C., Rechtenwald, T., Frick, T. ve Schmidt, M. 2010. A fast and flexible method for manufacturing 3D molded interconnect devices by the use of a rapid prototyping technology. Physics Procedia, 5, 561-572.

[2] Deckers J., Meyers S., Kruth J.P., Vleugels J. 2014. Direct selective laser sintering/melting of high density alumina powder layers at elevated temperatures. Physics Procedia, 56, 117 - 124.

[3] Zeng, K., Pal, D.i Stucker, B. 2012. A Review of Thermal Analysis Methods in Laser Sintering and Selective Laser Melting. Utwired. http://utwired. engr.utexas.edu/lff/symposium/proceedingsArc hive/pubs/Manuscripts/2012/2012-60

Zeng.pdf. (Erişim Tarihi: 02.01.2019).

[4] Thomas, D., 2009. The Development of Design Rules for Selective Laser Melting. Cardiff Metropolitan University. https://repository. cardiffmet.ac.uk/dspace/handle/10369/913. (Erişim Tarihi: 27.02.2019).

[5] Atzeni E. and Salmi A. 2015. Study on unsupported overhangs of AlSi10Mg parts processed by Direct Metal Laser Sintering. Journal of Manufacturing Processes, 20(3), 500506.
[6] Hanzl P.,Zetek M., Baksa T., Kroupa T. 2015. The Influence of Processing Parameters on the Mechanical Properties of SLM Parts. Procedia Engineering, 100, 1405 - 1413.

[7] Thompson, S.M.,Aspin, Z.S., Shamsaei, N., Elwany, A. ve Bian, L. 2015. Additive manufacturing of heat exchangers: Acasestudy on a multi-layered Ti-6Al-4V oscillatingheatpipe. Additive Manufacturing, 8, 163-174.

[8] Ahammed, N., Asirvatham, L.G. ve Wongwises, S. 2016. Thermoelectric cooling of electronic devices with nano fluid in a multiport mini channel heat exchanger. Experimental Thermal and Fluid Science, 74, 81-90.

[9] Al-Asadi, M.,Alkasmoul, F.S., Wilson, M.C.T. 2016. Heat transfer enhancement in a micro-channel cooling system using cylindrical vortex generators. International Communication in Heat and Mass Transfer, 74, 40-47.

[10] Au K.M., Yu K.M., Chiu W.K. 2011. Visibility based conformal cooling channel generation for rapid tooling. Computer-Aided Design, 43, 356-373.

[11] Hölker, R., Haase, M., Khalifa, N.B., Takkaya, A.E. 2015. Hot extrusion dies with conformal cooling channels produced by additive manufacturing. Aluminum Two Thousand World Congress and International Conference on Extrusion and Benchmark, ICEB 2015, 4838-4846.

[12] Sachs, E., Wylonis, E., Allen, S., Cima,M., Guo, H., 2000. Production of Injection Molding Tooling With Conformal Cooling Channels Using the Three Dimensional Printing Process. Polimer Engineering and Science, 40, 5.

[13] Wang, Y., Yu, K.M., Wang, C.C.L. 2015. Spiral and conformal cooling in plastic injection molding. Computer-Aided Design, 63, 1-11.

[14] Xia, C., Fu, F., Lai, J., Yao, X., Chen, Z. 2015. Conjugate heat transfer in fractal tree-like channels network heat sink for high-speed motorized spindle cooling. Applied Thermal Engineering, 90, 1032-1042.

[15] Hu, P., He, B., Ying, L. 2016. Numerical investigation on cooling performance of hot stamping tool with various channel designs. Applied Thermal Engineering, 96, 338-351.

[16] Eimsa-ard. K, Wannisorn. K. 2015. Conformal bubbler cooling for molds by metal deposition process. Computer-Aided Design, 69, 126-133.

[17] Du F.,Wang X.,Liu Y.,Li T., Yao M. 2016. Analysis of Non-uniform Mechanical Behavior for a Continuous Casting Mold Based on Heat Flux from Inverse Problem. Journal of Iron and Steel Research, 23(2), 83-91. 
[18] Koller, M., Walter, H., Hameter, M., 2016. Transient Numerical Simulation of the Melting and Solidification Behavior of $\mathrm{NaNO}_{3}$ Using a Wire Matrix for Enhancing of the Heat Transfer. Energies, 9, 205.

[19] Fang, W., He, X., Zhang, R., Yang, S., Qu, X. 2015. Evolution of stresses in metal injection molding parts during sintering. Transaction of Nonferrus Metals Society of China, 25, 552-558.

[20] Jimenes, C.A.R., Guerrero, A.H., Cervantes, J.G., Gutierrez, D.L., Valle, C.U.G. 2016. CFD study of constructal microchannel networks for liquidcooling of electronic devices. Applied Thermal Engineering, 95, 374-381.

[21] Silverio, V., Cardoso, S., Gaspar, J., Freitas, P.P., Moreira, A.L.N. 2015. Design, fabrication and test of an integrated multi-microchannel heatsink for electronics cooling. Sensors and Actuators, A 235, 14-27.

[22] Koli D. K., G. Agnihotri, R. Purohit. 2015. Advanced Aluminium Matrix Composite: The Critical Need of Automotive and Aerospace Engineering Fields. Materials today: proceeding, 2, 3032-3041.

[23] Djendel M., Allaoui O., Boubaaya R., 2017. Characterization of Alumina-Titania Coatings
Produced by Atmospheric Plasma Spraying on 304 SS Steel. Acta Physica Polonica A., 132(3), 538.

[24] Akar N., Boran K., Hozikliğil B., 2013. Kalıp Sıcaklığının Döküm Parça-Kalıp Arayüzey Isı Transfer Katsayısı Üzerine Etkisi. Journal of the Faculty of Engineering and Architecture of Gazi University, 28(2), 275-282.

[25] FLUENT Manual, Chapter 21: Modeling Solidification and Melting; ANSYS, Inc.: Canonsburg, PA, USA, 2001.

[26] Arankumar, S., Sreenivas Rao, K.V., Prasanna Kumar, T.S., 2008. Spatial variation of heat flux at the metal-mold interface due to mold filling effects in gravity die-casting. International Journal of Heat and Mass Transfer, 51(11), 2676-2685.

[27] Hallam, C. P. and Griffiths, W. D. 2004. A model of the interfacial heat-transfer coefficient for the aluminum gravity die-casting process. Metallurgical and materials transactions B., 35(4), 721-733.

[28] Durat M., Nart E., Kayıkcı R.,Özsert İ., 2006. Metal Döküm Kalıpların Sonlu Elemanlar Yöntemiyle Tekrarlı Termal Analizi. Timak-Tasarım İmalat Analiz Kongresi 2006 - Balıkesir, 549-557. 


\section{Ekler}

Ek A. Farklı soğutma kanal tasarımları

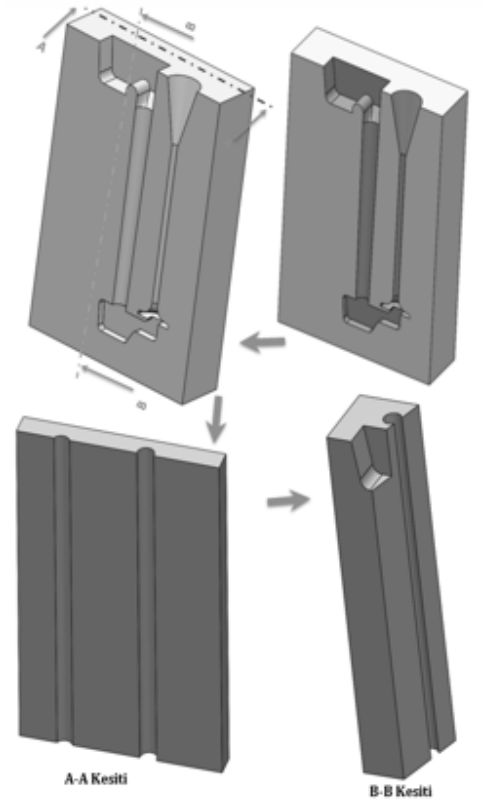

a) Klasik soğutma kanalı

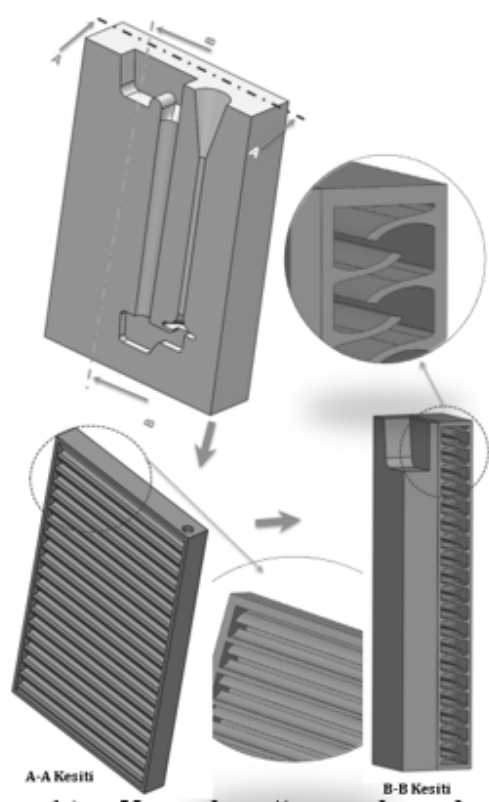

b) Kanatlı soğutma kanalı

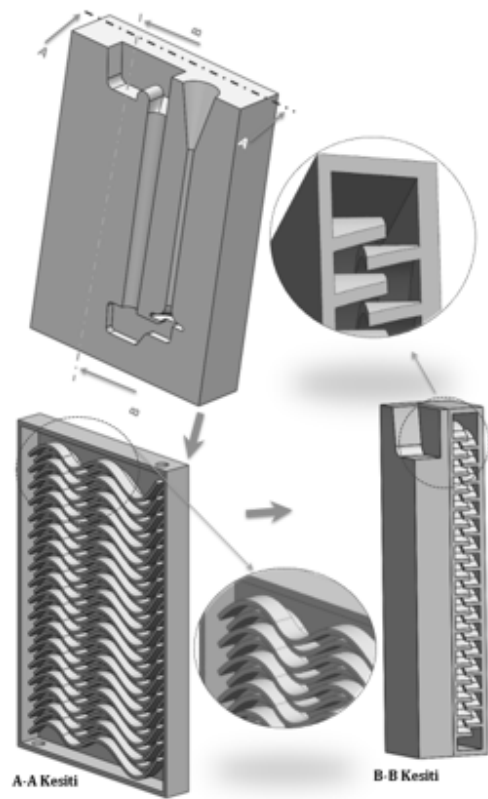

c) Dalgalı soğutma kanalı 
Ek B. Farklı soğutma kanalları için akış hacmi
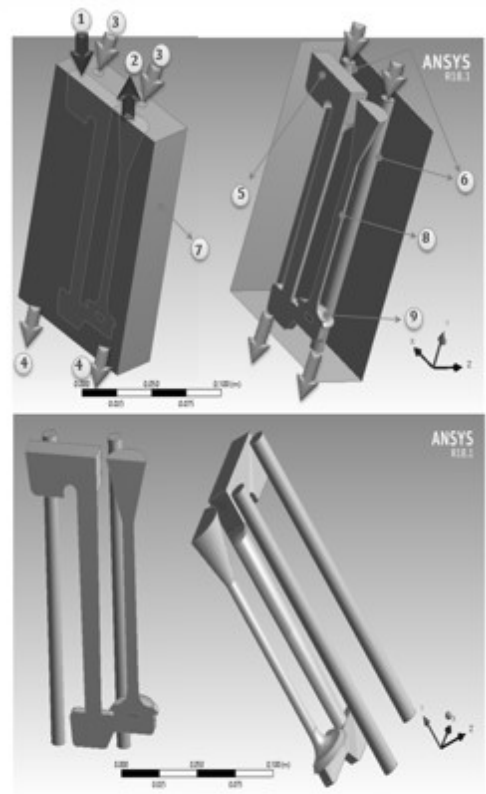

a) Klasik soğutma kanalı

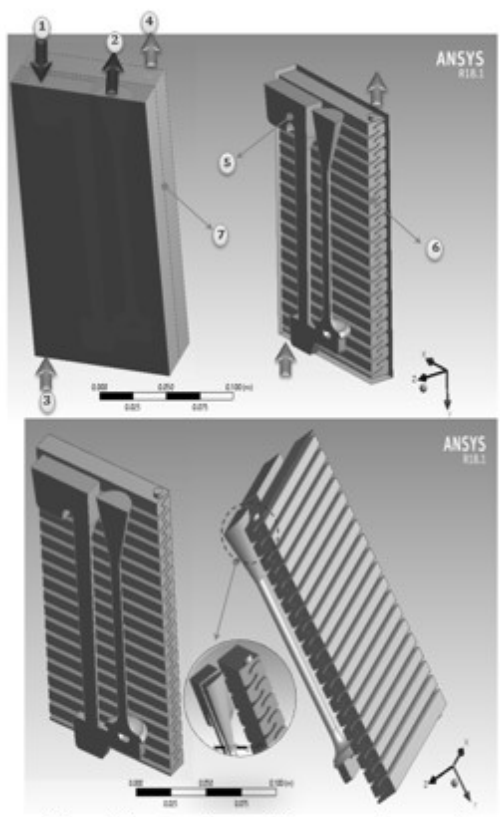

b) Kanatlı soğutma kanalı
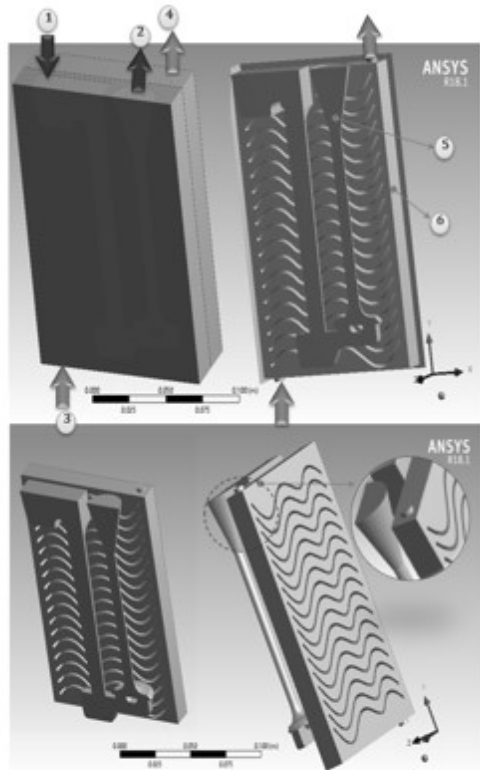

c) Dalgalı soğutma kanalı 
Ek C. Klasik soğutma kanalı için supap üzerinde zamana bağlı sıcaklık konturları

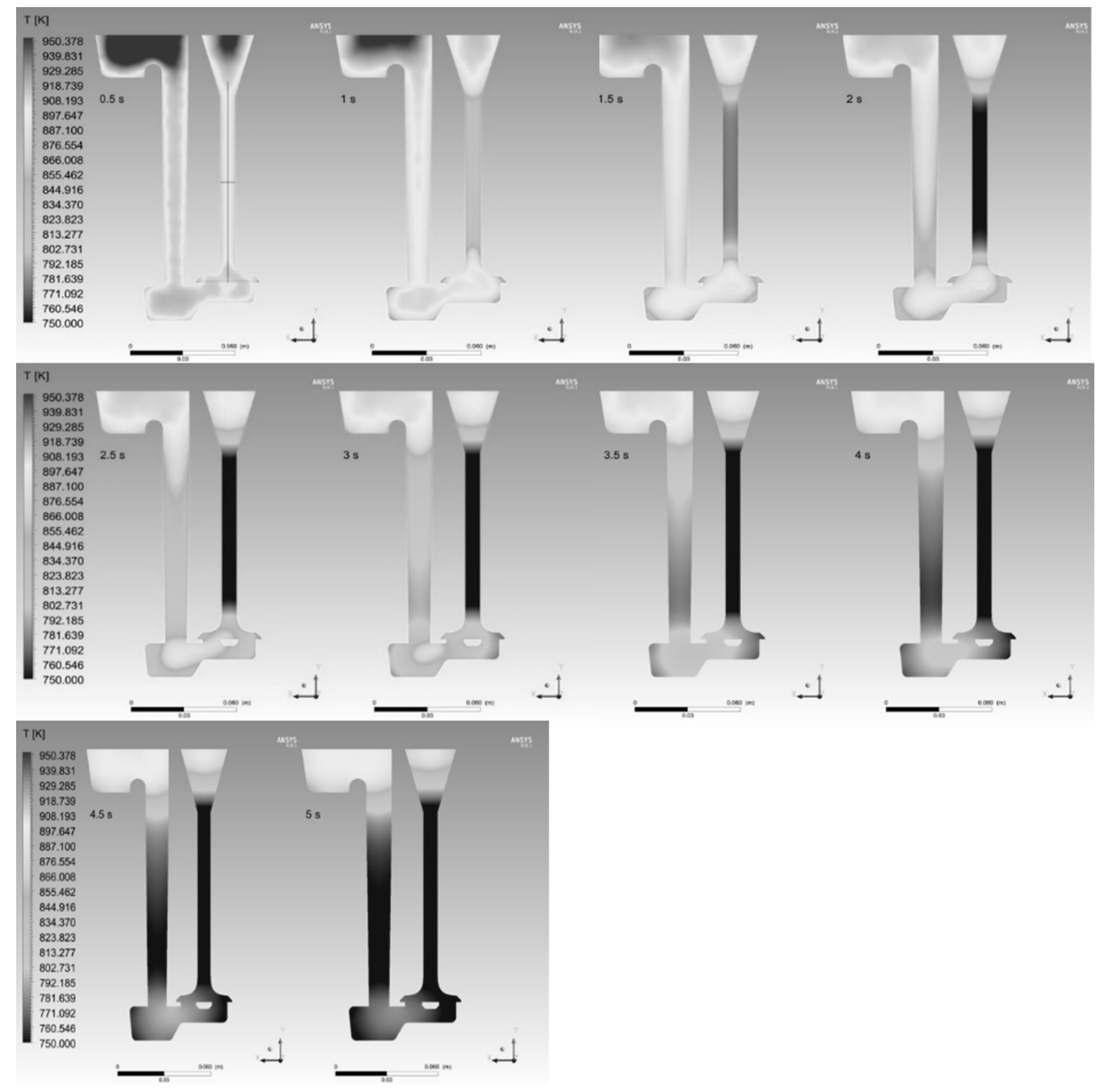


Ek D. Kanatlı soğutma kanalı için supap üzerinde zamana bağlı sıcaklık konturları

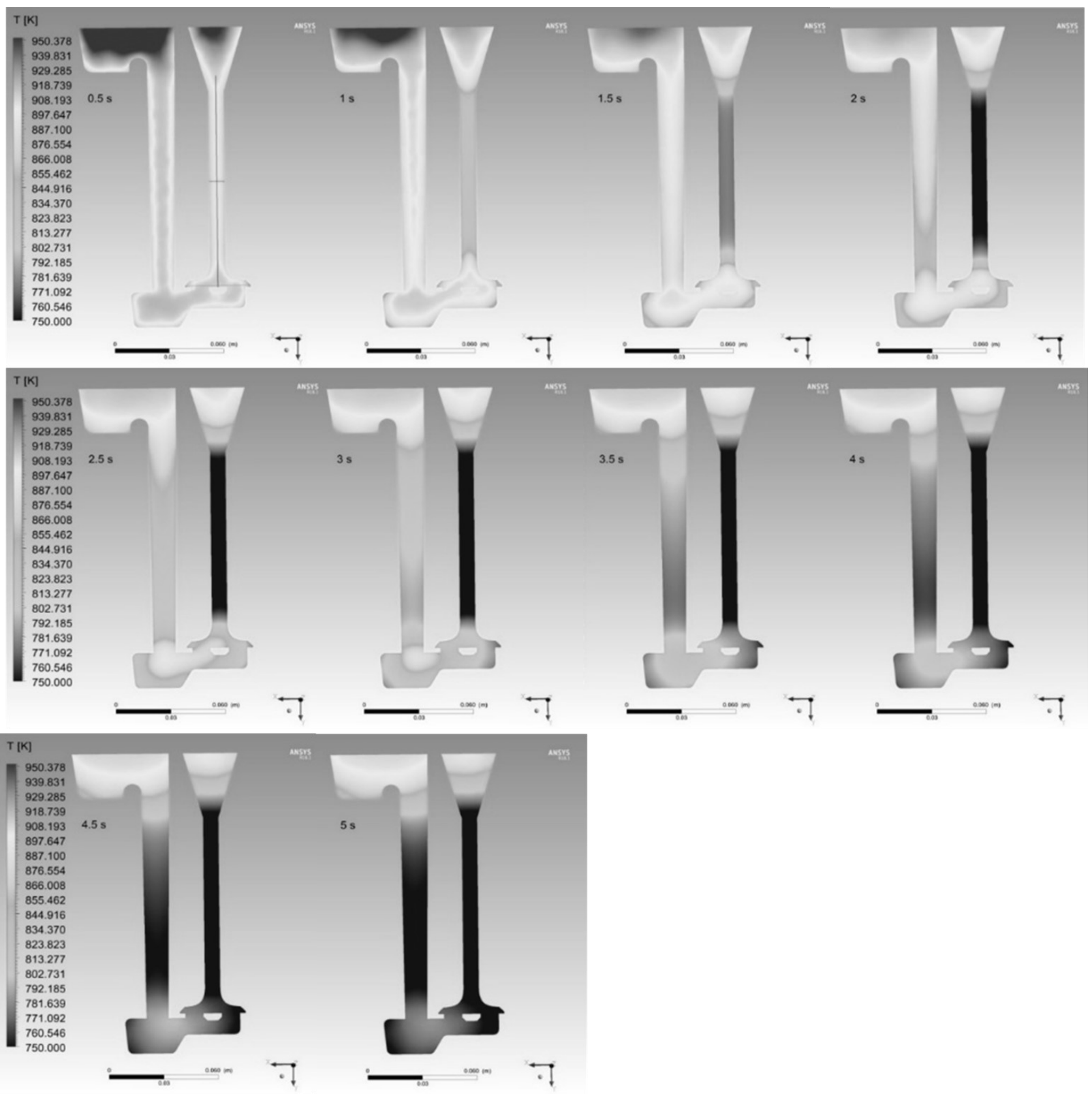


Ek E. Dalgalı soğutma kanalı için supap üzerinde zamana bağlı sıcaklık konturları

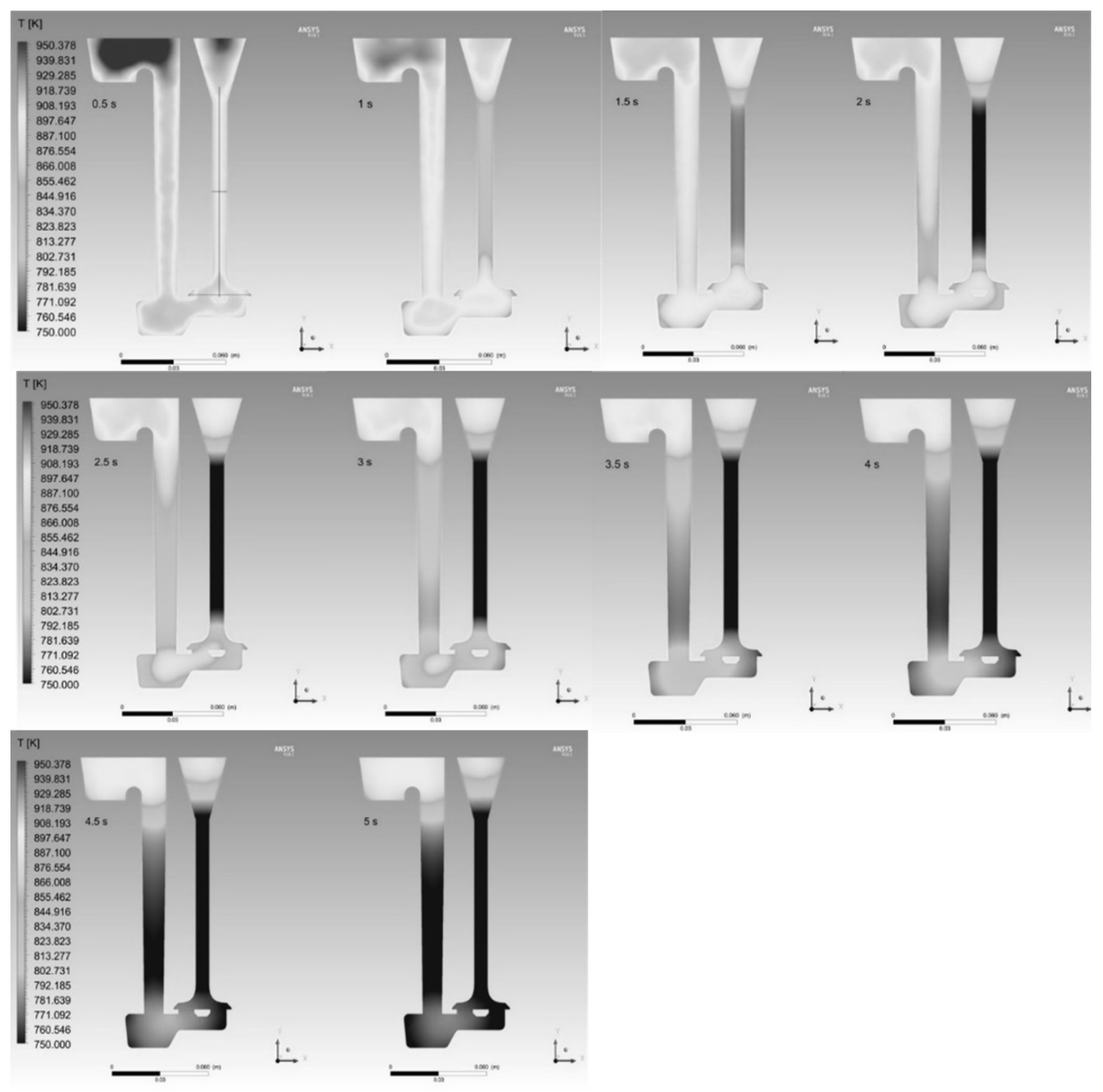


Ek F. Klasik soğutma kanalı için supap üzerinde zamana bağlı sıvı metal hacim oranı konturları

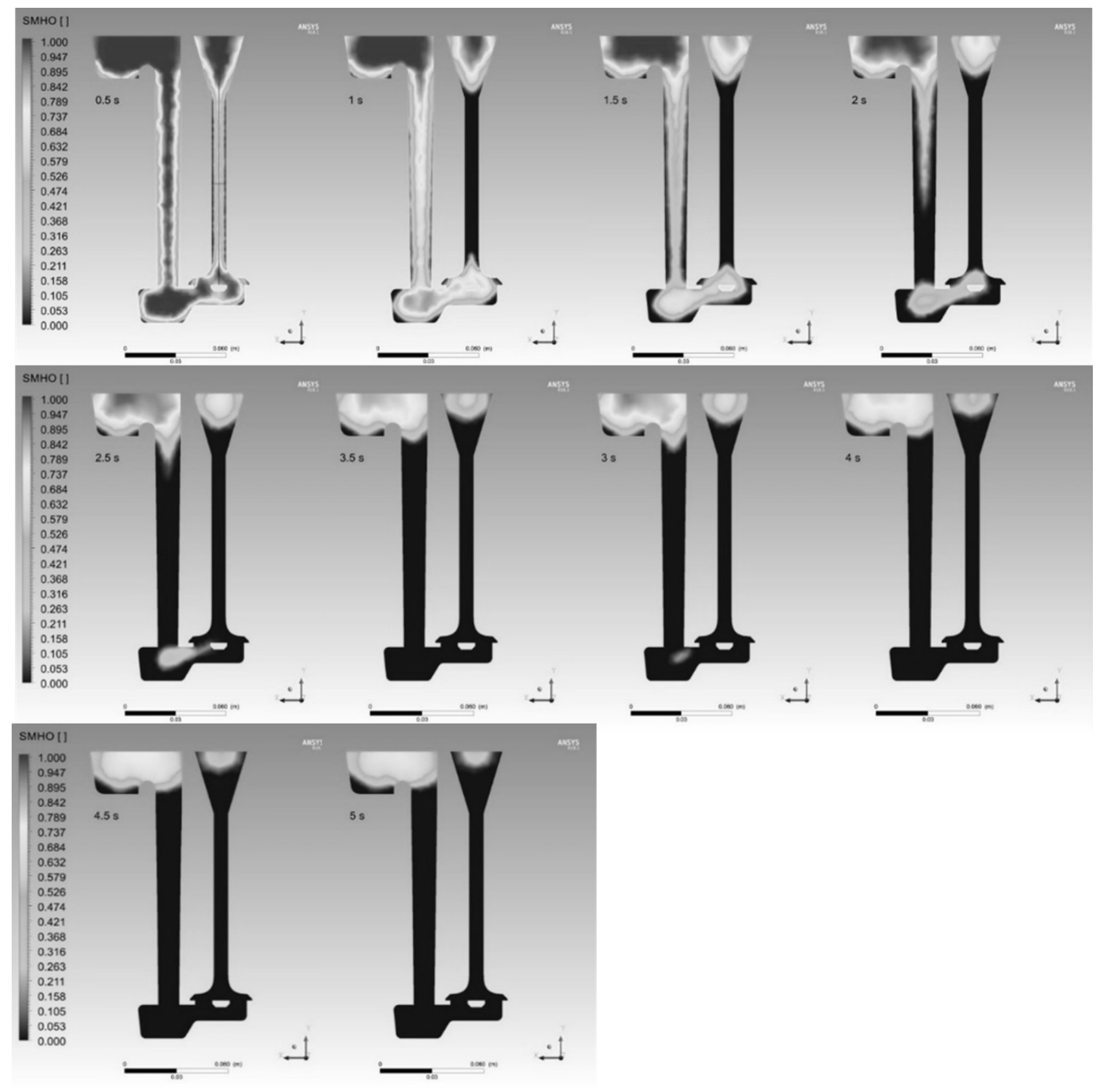


Ek G. Kanatlı soğutma kanalı için supap üzerinde zamana bağlı sıvı metal hacim oranı konturları

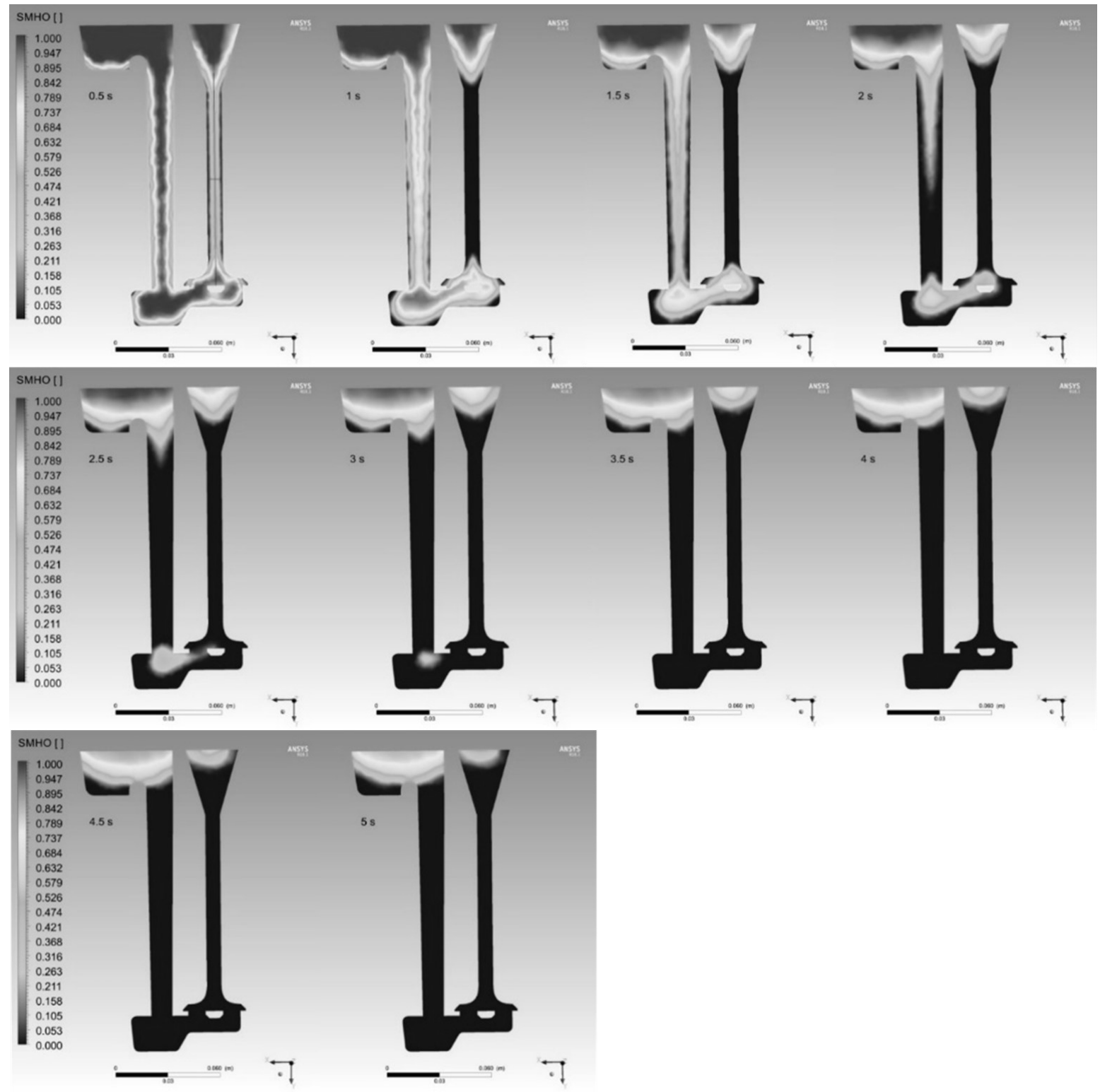


Ek H. Dalgalı soğutma kanalı için supap üzerinde zamana bağlı sıvı metal hacim oranı konturları

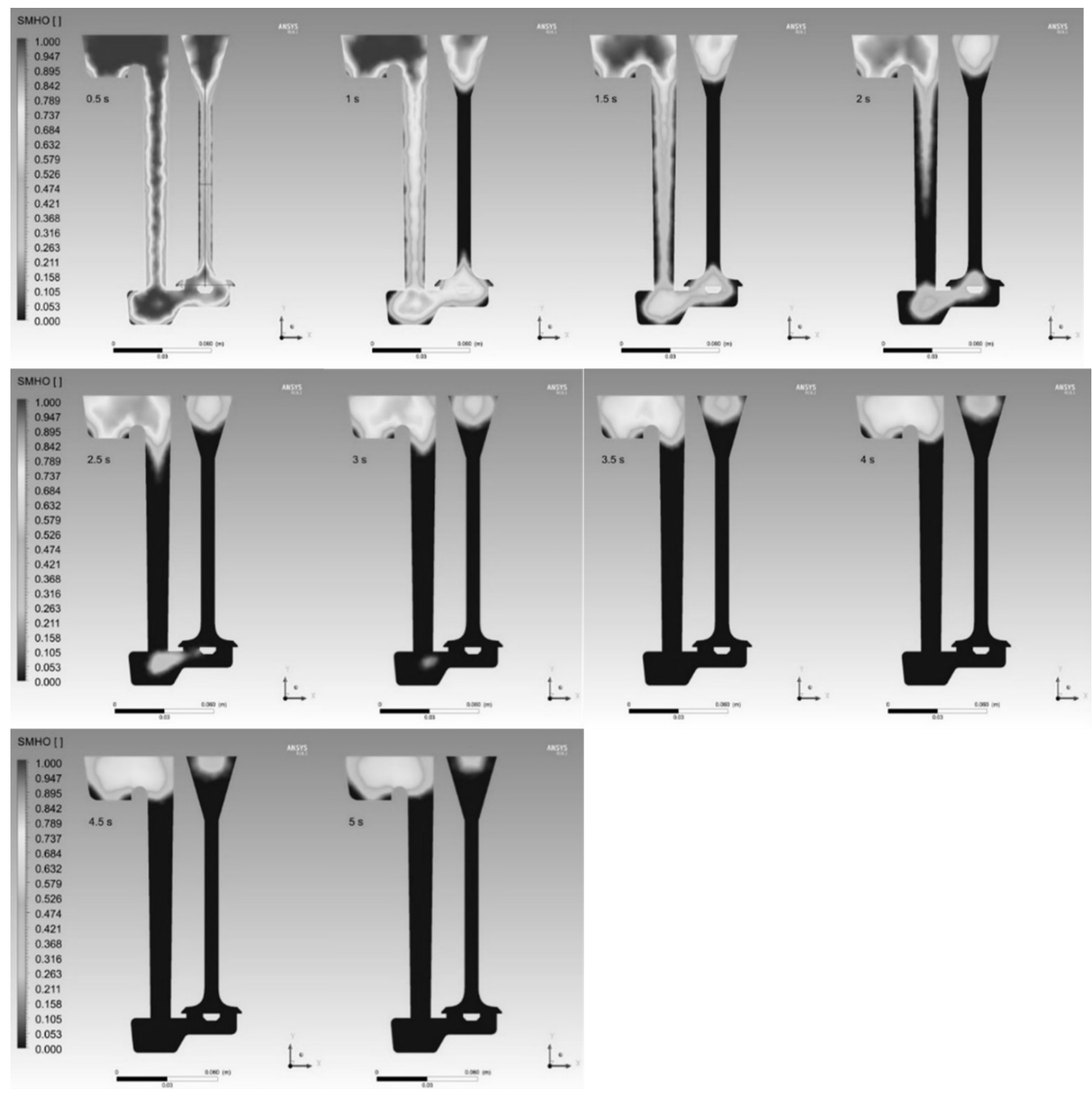

